\title{
ВИКОРИСТАННЯ ФРАЗЕОЛОГІЗМІВ У СТРУКТУРІ КУРСУ УКРАЇНСЬКОӤ МОВИ ЯК ІНОЗЕМНОЇ ЯК НЕОБХІДНИЙ ЧИННИК РОЗВИТКУ КОМУНІКАТИВНИХ НАВИЧОК ТА ВМІНЬ У ІНОЗЕМНИХ СТУДЕНТІВ
}

\author{
Рязанцева Д. В. \\ кандидат філологічних наук, \\ доиент кафедри мовної підготовки \\ Харківський національний автомобільно-дорожній університет \\ вул. Ярослава Мудрого, 25, Харків, Украӥна \\ orcid.org/0000-0002-3226-9165 \\ nannyhelp24@gmail.com
}

\begin{abstract}
Ключові слова: комунікація, фразеологічні одиниці, украӥнська мова, ментальність, адаптація.
\end{abstract}

\begin{abstract}
У статті розглядаються особливості вивчення фразеологічних одиниць на заняттях з української мови як іноземної (УКІ) для іноземних студентів, досліджується освітній, розвиваючий та виховний потенціал зазначених мовних одиниць. Аналізуються завдання, які постають перед викладачами української мови, що працюють 3 іноземними студентами, зокрема теоретично обгрунтовано необхідність використання фразеологізмів у структурі курсу УКІ та визначено роль фразеологізмів у формуванні комунікативних умінь та навичок іноземних студентів. Підкреслюється доцільність вивчення українських фразеологічних одиниць - носіїв специфічних рис української ментальності як допоміжного засобу успішної соціальної адаптації. У статті розглядаються такі комунікативні заходи, що можуть бути використані на заняттях з УКІ, як: вирішення проблемних завдань, дискусії, складання діалогів та текстів, рольові ігри. Подається характеристика комунікативних заходів, мовні приклади та аналіз доцільності їх використання на заняттях.

Розглядаються думки різних дослідників такої проблеми, наводиться аналіз науково-педагогічної літератури, що засвідчує відсутність єдиного погляду на методику та доцільність використання фразеологічних одиниць у структурі курсу УКІ серед методистів, викладачів ЗВО та науковців. Наголошується відсутність розробок вправ 3 УКІ 3 використанням фразеологізмів та 3 урахуванням специфічних рис української ментальності, що сприяли б успішній адаптації в іншомовному середовищі іноземних студентів. Аналізується термін «позитивне суб'єкт/ суб'єктне спілкування 3 носіями мови». Подається пропозиція щодо необхідності подальших досліджень виокремленої проблеми та розробки методичних рекомендацій щодо поліпшення вивчення фразеологічних одиниць у структурі курсу УКІ. Перспективним напрямом у розв'язанні зазначеної проблеми визначається лексикографічна робота зі складання мінісловників українських фразеологізмів з перекладом і еквівалентами англійською, французькою, арабською мовами. Матеріали статті можуть бути використані для позааудиторної роботи з іноземними студентами, що навчаються в Україні.
\end{abstract}




\title{
THE USAGE OF PHRASEOLOGICAL UNITS IN THE STRUCTURE OF THE COURSE OF UKRAINIAN AS THE NECESSARY FACTOR IN THE DEVELOPMENT OF COMMUNICATION SKILLS OF FOREIGN STUDENTS
}

\author{
Riazantseva D. V. \\ Candidate of Philological Sciences, \\ Associate Professor at the Department of Language Training \\ Kharkiv National Automobile and Highway University \\ Yaroslava Mudroho str., 25, Kharkiv, Ukraine \\ orcid.org/0000-0002-3226-9165 \\ nannyhelp24@gmail.com
}

Key words: communication, phraseological units, Ukrainian language, mentality, adaptation.
The article discusses the features of the usage of phraseological units in the structure of the course Ukrainian as foreign language (UFL) for foreign students, explores the educational, developmental and educational potential of these language units. The challenges that arise before teachers of Ukrainian language, who work with foreign students are analyzed, in particular, the need to use phraseology in the structure of the UFL course is theoretically substantiated and the role of phraseology in the formation of communicative skills of foreign students is determined. The expediency of studying Ukrainian phraseological units - carriers of specific features of Ukrainian mentality as a means of successful social adaptation is emphasized. The article considers the following communicative activities that can be used in UFL classes: problem solving, discussions, composing dialogues and texts, role-playing games. The characteristic of communicative activities, language examples and the analysis of expediency of their use at the lessons is given.

The opinions of various researchers of this problem are considered, the analysis of scientific and pedagogical literature is given, which testifies to the lack of a single view on the methodology and expediency of using phraseological units in the structure of UFL course among methodologists, university teachers and scientists. It is noted that there are no developments of exercises on UFL using phraseology and taking into account the specific features of the Ukrainian mentality, which would contribute to the successful adaptation of foreign students in a foreign language environment. The term "positive subject/subject communication with native speakers" is analyzed. A proposal is made on the need for further research on the selected problem and the development of guidelines for improving the study of phraseological units in the structure of the course of UFL. A promising direction in solving the outlined problem is the lexicographic work on compiling mini-dictionaries of Ukrainian phraseology with translation and equivalents in English, French, Arabic. Materials of the article may be used for extracurricular activities of foreign students studying in Ukraine.
Постановка проблеми. Вивчення фразеологізмів на заняттях з української мови як іноземної (УКІ) містить у собі значний освітній, розвиваючий та виховний потенціал. Успішне засвоєння фразеологічних одиниць іноземними студентами потребує цілеспрямованої, спеціально організованої роботи. На заняттях, присвячених вивченню фразеологізмів, доцільно використовувати цілий комплекс вправ, що дасть змогу іноземним студентам повною мірою засвоїти запропоновану тему та сформувати необхідні навички та вміння.
Особливу роль у досягненні такої мети відіграють вправи, що формують комунікативні вміння та навички.

Звичайно, українські філологи можуть запозичити всі найкращі надбання дисципліни «Російська мова як іноземна», але без розробки власних прогресивних методик, які б ураховували особливості ментальності українців, закріплені в мові, українська мова відіграватиме і надалі роль «країнознавчого елементу» та залишатиметься екзотикою. Над розробкою методики викладання української 
мови як іноземної працюють 3. Мацюк, О. Тростинська, Н. Ушакова, А. Чистякова, Л. Селіверстова, Т. Лагута, В. Лисенко та ін. Однак, на нашу думку, така царина залишається вільною для нових науково-методичних розвідок, активного творчого пошуку.

Як свідчить аналіз науково-педагогічної літератури, серед методистів, викладачів 3ВО та науковців відсутній єдиний погляд на те, як саме необхідно використовувати фразеологічні одиниці у структурі курсу УКІ, залишається суперечливим питання їх використання, відсутні розробки вправ з УКІ з використанням фразеологізмів та з урахуванням специфічних рис української ментальності, не доведена доцільність використання фразеологізмів як ефективного засобу успішної адаптації в іншомовному середовищі. Отже, питання використання фразеологізмів у структурі курсу УКІ розглядалося фрагментарно й досі залишається дискусійним.

Мета статті. 3 огляду на вищезазначене сформульована мета статті, яка полягає у теоретичному обгрунтуванні необхідності використання фразеологізмів у структурі курсу УКІ та визначення ролі фразеологізмів у формуванні комунікативних умінь та навичок іноземних студентів.

Виклад основного матеріалу дослідження. Слідом за О. Дударенко [2], М. Жовтобрюхом [3] та Є. Мінаковою [5] визначаємо фразеологічну одиницю як сталий вислів або мовний зворот, неподільний на окремі частини без втрати його значення, тотожний до прислів'я, тобто народного висловлювання повчального характеру, що в узагальненій формі виражає певні життєві закономірності, правила або істини, містить судження й оформлений за зразками синтаксично замкнених, семантично цілісних речень. Мовці залучають фразеологічні одиниці у процес комунікації як загальновідомі, загальноприйняті вислови, що перевірені досвідом багатьох поколінь і сприймаються як безапеляційні істини [2, с. 67-68].

Необхідність вивчення фразеологізмів студентами-іноземцями зумовлена перш за все потребою у соціальній адаптації. Студенти-іноземці, потрапляючи до іншомовного оточення, переживають культурний шок. Потреба в соціальній адаптації - глобальна проблема, 3 якою стикаються іноземці протягом першого року навчання. Крім того, $є$ необхідність подолання «психологічного бар'єру» для практичної щоденної комунікації. Тому одним із провідних завдань викладача-філолога має стати полегшення адаптаційного процесу, яке неможливе без пояснення ментальних відмінностей у мовних картинах світу. Мовна картина світу - продукт колективної свідомості, що містить базові уявлення певного етносу про морально-етичні норми, естетичні ідеали, варі- анти поведінки у різних ситуаціях тощо. Незнання особливостей комунікативної поведінки, характерних для носіїв мови, є джерелом більшості культурно-комунікативних помилок. Адже звичні для студентів, зумовлені національним менталітетом норми і штампи поведінки, у тому числі й комунікативної, стають непридатними, дисонують із загальновизнаними і прийнятними для носіїв мови, що вивчається. Отже, студенту-іноземцю доводиться якщо не «переучуватись», то «моделювати» інше ментально-комунікативне середовище, де «житиме» нова мова 3 усіма їі законами, необхідними для спілкування.

Комунікативні навички та вміння формуються за допомогою вправ, що мають творчий продуктивний характер, тому що в різних ситуаціях повсякденного спілкування, які завжди будуть для людини новими, доведеться шукати нові мовні засоби та інші фразеологічні одиниці, що відповідають ситуації. Для вирішення подібних завдань доцільним $\epsilon$ використання комунікативних заходів на заняттях з УКІ. Ефективність цих заходів заснована на тому, щоб комуніканти були поставлені в умови, у яких вони змушені були б спілкуватися та обмінюватися думками з використанням фразеологічних одиниць на тему, визначену викладачем. Велике значення для успішного проведення комунікативних заходів мають два взаємопов'язані фактори: зацікавленість у темі та максимальне залучення студентів у іiі активне обговорення. Відправною точкою для проведення комунікативних заходів, які, своєю чергою, передбачають використання комунікативних фразеологічних одиниць, є реальні життєві ситуації. Для цього у процесі навчання необхідно використовувати прийоми, що забезпечують реальне спілкування: вирішення проблемних завдань, дискусії, складання діалогів та текстів, рольові ігри.

У межах комунікативних заходів на основі фразеологічних одиниць перераховані методичні прийоми наповнюються новим змістом. Використання фразеологізмів під час формування комунікативних навичок та вмінь допомагає запобігти виникненню мовного бар'єру у процесі реального спілкування. Це значною мірою забезпечується також повним виключенням під час заняття рідної мови. Під час проведення комунікативних заходів вислови, стійкі сполучення слів та фразеологічні одиниці, необхідні у кожній ситуації спілкування, рекомендується виписати на дошку та звернути на них увагу студентів до проведення заходу.

Проблемні завдання - вдала форма проведення комунікативного заходу. Їхня мета у такому разі - навчити стисло висловлювати свою думку, вносити пропозиції, запитувати інформацію, порівнювати, погоджуватися або спростовувати твердження інших учасників заходу, при цьому 
використовувати раніше вивчену лексику, у тому числі найбільш поширені фразеологічні одиниці. Як проблемні завдання студентам можна запропонувати такі:

1. Проведіть інтерв'ю на тему «Які цікаві фразеологізмі ви знаєте?» (вище лоба очі не ходять; дешева рибка, погана юшка; не родись у платтячку, а родись у щастячку; хто пізно встає, тому хліба не стає; гарні гості, та не в пору і т. д.).

2. Розкажіть про свій маршрут до університету; запитайте у незнайомої людини, як дістатися певної вулиці; розкажіть про свою країну. Використайте фразеологізми такої тематичної групи (де Pим, де Крим; язик і до Кракова доведе; нема на світі другої Украӥни, немає другого Дніпра і т. д.).

Дискусія, як відомо, носить більш складний характер та для ії проведення необхідно, щоб студенти мали певний лінгвістичний досвід, а також уміння формулювати, аргументувати та відстоювати свою думку, отже, використовувати більше фразеологічних одиниць. Бажання реагувати, аргументувати, сперечатися на цікаву тему - це стимул для породження непідготовленої мови, що сприяє розвитку та формуванню комунікативних навичок та вмінь. Дискусія належить до найбільш продуктивних видів комунікативних заходів. Студентам можна запропонувати такі теми для проведення дискусій:

1. «Що краще: гірка правда чи солодка брехня?». Використайте фразеологізми такої тематичної групи (морочити голову; бабусині казки; правда, як олива, наверх вийде і т. д.).

2. «Роль праці в житті людини». Використайте фразеологізми такої тематичної групи (госnодар той, хто працуює; де нема праці, там сади не иявітуть; один лікується відпочинком, а другий працею; хто працююе, той радість чує і т. д.).

Створення розповіді або діалогу стимулює студентів до зв'язного висловлювання, активізує використання не лише окремих структур, висловів та фразеологічних одиниць, над якими ведеться робота у певний момент, але й більшої кількості супутнього матеріалу [4, с.189]. Тому цей вид роботи краще використовувати для повторення вивченого раніше матеріалу. Мета цього заходу - використання та взаємодія всіх елементів мови, розвиток швидкості мови, вміння розкривати певну тему, імпровізувати. Подібні завдання можуть мати такий вигляд:

1. Складіть короткі діалоги, використовуючи фразеологізми тематичної групи «Моя родина» (який батько, такі й діти; яка мати, така й дочка; де чоловік - голова, а жінка - серие, там $i$ сім'я щзаслива і т. д.).

2. Керівник курсової роботи дорікає студентові, що він мало працює. Студент виправдовується великим навантаженням 3 інших дисциплін.
Ще одним ефективним засобом залучення студентів у комунікацію 3 використанням фразеологічних одиниць є рольові ігри. Їхня мета-створити на занятті таку атмосферу, щоб використовувати лексику та фразеологічні одиниці, вживання яких в іншій ситуації було б неможливим або штучним та нецікавим.

Під час проведення рольової гри можливі два варіанти: студенту пропонується роль іншої людини; студент грає самого себе, який потрапив у певну ситуацію.

Необхідно виділити час, щоб студенти могли обдумати свої ролі та дії. Варто дозволити робити записи, але під час виступу слід заохочувати імпровізацію, а не читання підготовленого тексту. Важливо, щоб вони не боялися робити помилки, тому що помилка - це частина процесу навчання.

Можливими $є$ такі теми проведення рольових ігор на заняттях з УКІ з використанням фразеологізмів:

1. Розмова по телефону. Після зустрічі 3 колишніми однокласниками дві найкращі подруги обговорюють тих, хто був присутній на заході. Використайте фразеологізми, що характеризують людину та людські якості характеру (абсолютний нуль; велика шишка; важлива птаха; шукач пригод; у боргу як і шовку; йде вгору; здоровий як дуб; вовк у овечій шкурі; язик як помело; як пава; має цุаря в голові; золота голова; гаряча голова і т. д.).

2. Хлопці, що грають на вулиці, шукають кішку, що загубилася. Використайте запропоновані фразеологізми для характеристики такої ситуації (зникнути як голка в соломі (снігу); як за водою піти; шукати вітра в полі і т. д.).

Висновки. Таким чином, засвоєння фразеологічних одиниць студентами значною мірою спрощує процес комунікації, сприяє формуванню мотивації до спілкування. Володіючи навичками спілкування 3 використанням фразеологічних одиниць, іноземні студенти рідше стикаються із такими проблемами, як перехід з рідної мови на іноземну і т.д. Практика доводить, що недостатнє ознайомлення 3 мовною картиною світу спричиняє безліч комунікативних проблем у житті іноземних студентів, стає прикрим джерелом ситуацій, коли їхня поведінка сприймається як неадекватна. Перше враження, що складається у студента-іноземця про соціум країни, у мовному середовищі якої він перебуває, багато в чому визначатиме його комунікативну поведінку. Тому чим більш обізнаним, чим більш підготовленим до реального спілкування буде студент, тим більш позитивним буде подальший процес і засвоєння мови, і оволодіння майбутньою професією. Саме тому проведення комунікативних заходів 3 використанням фразеологічних одиниць не тільки значно збагачує заняття, а й робить їх корисними 
для студентів та підтримує інтерес до вивчення української мови. Розуміння особливостей національної мовної картини світу необхідне для успішного оволодіння іноземною мовою. Фразеологічні одиниці - одна 3 найкращих ілюстрацій цих особливостей. Вивчення паремій покликане значно полегшити знайомство з іншоментальною мовною картиною світу, прискорити період культурологічної адаптації, а у перспективі забезпечити позитивне суб'єкт/суб'єктне спілкування 3 носіями мови.
Репрезентоване дослідження не вичерпує всього кола питань, пов'язаних із самостійною роботою іноземних студентів, що викликає необхідність подальших досліджень виокремленої проблеми та розробку методичних рекомендацій щодо поліпшення вивчення фразеологічних одиниць у структурі курсу УКІ. Перспективним напрямом у розв'язанні зазначеної проблеми $\epsilon$, на нашу думку, лексикографічна робота зі складання мінісловників українських фразеологізмів з перекладом i, можливо, еквівалентами англійською, французькою, арабською мовами.

\section{ЛІТЕРАТУРА}

1. Акишина А.А., Каган О.Е. Учимся учить: для преподавателя русского языка как иностранного. Москва : Русский язык, 2008. 255 с.

2. Дударенко О. Українські паремії як автосемантеми народного дискурсивного мовлення. Лінгвістичні дослідження. 2001. № 6. С. 67-72.

3. Жовтобрюх М. Курс сучасної української літературної мови. Київ : Вища школа, 1972. 404 с.

4. Корнилов О. Языковые картины мира как производные национальных менталитетов. Москва : ЧеРо, 2003. $349 \mathrm{c}$.

5. Минакова Е.Е. Современная русская идиоматика : учебное пособие для иностранцев, изучающих русский язык. Москва : Русский язык, 2005. 131 с.

\section{REFERENCES}

1. Akishina, A.A., Kagan, O.E. (2008). Uchimsya uchit': dlya prepodavatelya russkogo yazyka kak inostrannogo [Learning to Learn: for a Teacher of Russian as a foreign language]. Moscow : Russkij yazyk [in Russian].

2. Dudarenko, O. (2001). Ukrainski paremii yak avtosemantemy narodnoho dyskursyvnoho movlennia [Ukrainian paremias as autosemanthems of folk discursive speech]. Lingvistuchni doslidzennia. Vol. 6. P. 67-72 [in Ukrainian].

3. Zhovtobriukh, M. (1972). Kurs suchasnoi ukrainskoi literaturnoi movy [Course of modern Ukrainian literary language]. Kyiv : Vyshcha shkola [in Ukrainian].

4. Kornilov, O. (2003). Yazykovye kartiny mira kak proizvodnye nacional'nykh mentalitetov [Linguistic pictures of the world as derivatives of national mentality]. Moskva: ChERo [in Russian].

5. Minakova, E.E. (2005). Sovremennaya russkaya idiomatika: Uchebnoe posobie [Modern Russian idioms: a study guide]. Moscow [in Russian]. 